\title{
Risk Assessment of Ethylhexyl Dimethyl PABA in Cosmetics
}

\author{
Chi Rim Sung', Kyu-Bong Kim², Joo Young Lee ${ }^{3}$, Byung-Mu Lee ${ }^{4}$ and Seung Jun Kwack' \\ ${ }^{1}$ Department of Bio Health Science, College of Natural Science, Changwon National University, Changwon, Korea \\ ${ }^{2}$ College of Pharmacy, Dankook University, Cheonan, Korea \\ ${ }^{3}$ BK21Plus Team, College of Pharmacy, The Catholic University of Korea, Bucheon, Korea \\ ${ }^{4}$ College of Pharmacy, Sungkyunkwan University, Suwon, Korea
}

\begin{abstract}
Ethylhexyl dimethyl para-aminobenzoic acid (PABA) is an oily yellow liquid derivative of water-soluble PABA commonly used in sunscreen. Ethylhexyl dimethyl PABA is widely used as an ingredient in many cosmetics at an average concentration of $1.25 \%(0.5-2.0 \%)$ in Korea. Previous studies, including those involving animals, have demonstrated that ethylhexyl dimethyl PABA is toxic to the following four organs: testis, epididymis, spleen, and liver. In addition, experiments using human keratinocytes found that ethylhexyl dimethyl PABA inhibits cell growth and DNA synthesis at low concentrations, and halted the cell cycle of MM96L cells (human melanoma cell line) at the G1 phase. Despite limited clinical data in humans, many studies have confirmed increased mutagenicity of ethylhexyl dimethyl PABA following exposure to sunlight, which suggests that this molecule is likely to contribute to onset of sun-induced cancer despite protecting the skin through absorption of UVB. For risk assessment, the no observed adverse effect level (NOAEL) chosen was $100 \mathrm{mg} / \mathrm{kg} \mathrm{bw} /$ day in a 4 weeks oral toxicity study. Systemic exposure dosage (SED) was $0.588 \mathrm{mg} / \mathrm{kg}$ bw/day for maximum use of ethylhexyl dimethyl PABA in cosmetics. Based on the risk assessment and exposure scenarios conducted in this study, the margin of safety (MOS) was calculated to be 180.18 for a sunscreen containing $8 \%$ ethylhexyl dimethyl PABA, which is the maximum level allowed by the relevant domestic authorities.
\end{abstract}

Key words: Ethylhexyl dimethyl PABA, Cosmetics, Sunscreen, Risk assessment, Toxicity

\section{INTRODUCTION}

Ethylhexyl dimethyl PABA (CAS No. 21245-02-3) is an organic derivative of water-soluble PABA (4-aminobenzoic acid) included in sunscreen and other cosmetics. It is a yellow water-insoluble oily liquid with an ester bond formed by condensation of 2-ethylhexanol and dimethylaminobenzoic acid (Fig. 1). Ethylhexyl dimethyl PABA is

Correspondence to: Seung Jun Kwack, Department of Bio Health Science, College of Natural Science, Changwon National University, 20 Changwondachak-ro, Uichang-gu, Changwon, Gyeongnam 51140, Korea

E-mail: sjnkwack@changwon.ac.kr

This is an Open-Access article distributed under the terms of the Creative Commons Attribution Non-Commercial License (http:// creativecommons.org/licenses/by-nc/3.0) which permits unrestricted non-commercial use, distribution, and reproduction in any medium, provided the original work is properly cited. also known as padimate O, OD-PABA, or octyl dimethyl p-aminobenzoate (Table 1). The Ministry of Food and Drug Safety (MFDS) and US Food and Drug Administration (FDA) mandate that its concentration in any cosmetic product shall not exceed 8\% (1). Previous animal studies showed that high concentrations of ethylhexyl dimethyl PABA may be toxic to the epididymis and caution should be exercised when administering this substance to infants

List of Abbreviations: ACGIH, Association Advancing Occupational and Environmental Health; EHMC, Ethylhexyl p-methoxycinnamate; EWG, Environmental Working Group; EtBr, Ethidium bromide; Ethylhexyl dimethyl PABA, Ethylhexyl dimethyl paraaminobenzoic acid; FDA, US Food and Drug Administration; IARC, International Agency for Research on Cancer; MDTA, Metered-dose topical aerosol; MED, Minimal erythema dose; MFDS, Ministry of Food and Drug Safety; MOS, Margin of safety; NOAEL, No observed adverse effect level; NTP, US National Toxicology Program; OSHA, Occupational Safety and Health Administration; SCC, Scientific Committee on Cosmetology; SED, Systemic exposure dosage; UV, Ultra violet. 
<smiles>CCCCC(CC)COC(=O)c1ccc(N(C)C)cc1</smiles>

Fig. 1. Chemical structure of ethylhexyl dimethyl PABA.

Table 1. Ethylhexyl dimethyl PABA nomenclature and classification

\begin{tabular}{ll}
\hline \hline CAS No. & $21245-02-3$ \\
EINECS No. & $244-289-3$ \\
INCI name & Ethylhexyl Dimethyl PABA \\
IUPAC name & 2-Ethylhexyl 4-(dimethylamino)benzoate \\
Synonyms & Padimate O \\
& Octyl dimethyl $p$-aminobenzoate, \\
& Octyl dimethyl PABA \\
& 2-Ethylhexyl $p$-(dimethylamino)benzoate \\
& OD-PABA
\end{tabular}

Adopted from Hazardous Substances Data Bank (HSDB) \& ChemIDplus (2).

younger than six months of age due lack of understanding of its metabolism and absorption (2). Previous risk assessment data for ethylhexyl dimethyl PABA includes potential toxicity data and national and international regulations only. The present study summarizes a risk assessment that included determination of the margin of safety (MOS) at concentrations in cosmetics allowed by domestic authorities, a summary of existing experimental toxicity data, and exposure data associated with the amount of use in domestic cosmetic products.

\section{PHYSICAL AND CHEMICAL PROPERTIES}

The range of purities of ethylhexyl dimethyl PABA used as a raw material for cosmetics is approximately 98$99.5 \%$. It is an oily yellow liquid state with oil characteristics. It has a molecular weight of 277.4053. It is soluble in alcohol, and strong acid and base, but is insoluble in water and acetic acid (Table 2).

\section{COSMETIC USE}

Ethylhexyl dimethyl PABA is used in sunscreen and in a variety of beauty products. According to the Environmental Working Group (EWG) database, it is used in many products including lipstick, conditioner, shampoo, antiaging agents, hair spray, and sunscreen. Use of ethylhexyl
Table 2. Chemico-physical properties of ethylhexyl dimethyl PABA

\begin{tabular}{ll}
\hline \hline Physical property & Yellow liquid with oil characteristics \\
Molecular weight & 277.4053 \\
pKa & 6.027 \\
Boiling point & $387.8^{\circ} \mathrm{C}$ at $760 \mathrm{mmHg}$ \\
Melting point & $242.5-243.5^{\circ} \mathrm{C}$ \\
Ignition point & $124.1^{\circ} \mathrm{C}$ \\
Steam pressure & $7.7 \times 10^{7} \mathrm{mmHg}$ at $25^{\circ} \mathrm{C}$ \\
Specific gravity & 0.99 \\
Solubility & Dissolved in alcohol, $\mathrm{HCl}, \mathrm{KOH}$ \\
& Not dissolved in acetic acid \\
& Dissolved in water at $25^{\circ} \mathrm{C}$ if $5.3 \times 10^{3} \mathrm{mg} / \mathrm{L}$ \\
Density & $1.0 \pm 0.1 \mathrm{~g} / \mathrm{cm}^{3}$ \\
\hline
\end{tabular}

Adopted from HSDB (2).

dimethyl PABA in non-cosmetic products has not been reported in Korea. According to a survey conducted by the MFDS the average concentration of ethylhexyl dimethyl PABA in cosmetic products is $1.25 \%$ (ranging from 0.5 $2.0 \%)$.

\section{HAZARD IDENTIFICATION}

Single and repeated dose toxicity studies of ethylhexyl dimethyl PABA have identified various toxicities including skin irritation, reproductive toxicity, genotoxicity, and phototoxicity. Repeated dosing of experimental animals resulted in organ toxicity and organ pigmentation. The major proposed mechanism of ethylhexyl dimethyl PABA toxicity is DNA damage by light-modified ethylhexyl dimethyl PABA.

General toxicity. In an acute toxicity study of ethylhexyl dimethyl PABA, the $\mathrm{LD}_{50}$ in rats was $14,900 \mathrm{mg} / \mathrm{kg}$ (3) and no irritation was observed in a human patch test using white Vaseline ${ }^{\circledR}$ mixed with $8 \%$ ethylhexyl dimethyl PABA.

According to a report by the Scientific Committee on Cosmetology (SCC) (1999) (4), a 4-week oral administration study was conducted in rats in accordance with GLP principles. Ethylhexyl dimethyl PABA was administered orally (by gavage) at doses of $0,100,300$, and 1,000 mg/ $\mathrm{kg} /$ day (Groups 1, 2, 3, and 4, respectively) to 10 male and female rats per group. An additional 5 male and 5 female rats were added to Groups 1 and 4 to evaluate the convalescence stage. No clinical symptoms were observed except salivation in Group 4 and decreased weight in Group 4 three to four weeks after administration, which did not normalize following the convalescence period. Gross inspections during autopsies of the animals found that the capsule of the spleen was severely degraded in one female in Group 4. A male in Group 4 (4/10) exhibited a softened testis and 8 males exhibited reduced testis size. No 
prostate, epididymis, or seminal vesicle abnormalities were observed. Three out of the five males in the Group 4 convalescence group exhibited reduced testis size. A female rat in Group 4 showed increased spleen weight, and the females in Groups 3 and 4 exhibited increased liver weight. Furthermore, the males in Group 4 exhibited liver weight gain and pituitary gland weight loss. Among the animals in the convalescence group, the males in Group 4 exhibited kidney weight gain, but showed no changes in testis or pituitary gland weights. Histopathological examinations showed moderate or moderately severe testicular atrophy in all males in Group 4 and epididymal edema in seven out of the ten males in Group 4. All males in Group 4 had spleen pigmentation, but spleen pigmentation was more conspicuous in the females in Group 3 and was extensive in the females in Group 4. The NOAEL was determined at $100 \mathrm{mg} / \mathrm{kg} /$ day based on pigmentation of the spleen (5). The SCC determined that this NOAEL may have been too conservative, so a NOAEL value of $300 \mathrm{mg} / \mathrm{kg} / \mathrm{day}$ was assigned to ethylhexyl dimethyl PABA (4).

No toxicity was observed in 20 rabbits administered 140 or $280 \mathrm{mg} / \mathrm{kg} /$ day of ethylhexyl dimethyl PABA for 13 weeks (4).

Reproductive and developmental toxicity. When 2 $\mathrm{mL} / \mathrm{kg}$ daily ethylhexyl dimethyl PABA was applied to the skin of rats at 6 to 16 days of pregnancy, wavy ribs were observed on both sides of 7/56 fetuses and on one side of 2/56 fetuses. However, these observations were not attributed to ethylhexyl dimethyl PABA toxicity, as the rat species used in this study commonly exhibit wavy ribs (4).

According to a report by Erol et al. (6), dermal exposure to OD-PABA did not affect pubertal development or thyroid function in female or male rats. As such, OD-PABA was not classified as an endocrine disrupting chemical.

Mutagenicity/Genotoxicity. In vivo micronucleus testing was conducted on mice to evaluate mutagenesis. Ethylhexyl dimethyl PABA $(5,000 \mathrm{mg} / \mathrm{kg})$ was intraperitoneally injected into three groups of mice $(n=10$ mice per group; 30,48 , or $72 \mathrm{hr}$ ), resulting in no mutagenesis (3).

A chromosomal aberration test was performed in human lymphocytes. This assay is based on metabolic activation in response to the S9 mix. Ethylhexyl dimethyl PABA was dissolved in ethanol at concentrations of 315 to $5,010 \mu \mathrm{g} /$ $\mathrm{mL}$. No chromosomal aberrations were observed (4).

Carcinogenicity. Ethylhexyl dimethyl PABA is not considered carcinogenic per International Agency for Research on Cancer (IARC), Association Advancing Occupational and Environmental Health (ACGIH), US National Toxicology Program (NTP), and Occupational Safety and Health Administration (OSHA) (7).
Ocular irritation. Two percent ethylhexyl dimethyl PABA mixed with mineral oil was applied to the eyes of rabbits. No irritation was reported when both eyes are washed and left unattended (3).

A slight irritation was observed in rabbit mucous membranes during a Draize test with $2 \%$ and $5 \%$ ethylhexyl dimethyl PABA in mineral oil (4).

Skin irritation. Five percent ethylhexyl dimethyl PABA mixed with mineral oil applied to rabbit skin did not cause irritation $(3,8)$. In addition, a patch containing ethylhexyl dimethyl PABA dissolved in $4 \%$ white Vaseline ${ }^{\circledR}$ affixed to adult volunteers did not cause skin sensitization (3).

No irritation was observed following application of 5\% ethylhexyl dimethyl PABA to normal and damaged rabbit skin for $24 \mathrm{hr}(4)$.

A human patch test study showed no incidence of irritation following application of yellow soft paraffin with 5\% ethylhexyl dimethyl PABA for $48 \mathrm{hr}$ (4).

When $1 \mathrm{mg} / \mathrm{mL}$ of estradiol was prescribed during the autumn and winter seasons to postmenopausal women (4 persons), women receiving hormone replacement therapy, women with sensitivity to ethylhexyl dimethyl PABA, women with epilepsy, or women prescribed medications to control liver metabolism (aged between 54 and 63, body weight between 67 and $93 \mathrm{~kg}$ ) along with ethylhexyl dimethyl PABA applied to their arm over a $10 \mathrm{~cm}^{2}$ area, daily for nine days, no skin irritation was observed (9).

Skin sensitization. Five percent ethylhexyl dimethyl PABA in mineral oil did not cause skin sensitization in guinea pigs. In addition, $50 \mu \mathrm{L}$ of $0.1 \%$ ethylhexyl dimethyl PABA in saline was injected into ten guinea pigs, followed by nine additional $0.1 \mathrm{~mL}$ injections administered across three weeks. The guinea pigs did not exhibit sensitization when challenged with a $0.05 \mathrm{~mL}$ dose after a 12week resting phase (4).

No skin sensitization was observed in humans following application of $1.5 \%$ or $4 \%$ ethylhexyl dimethyl PABA mixed with white Vaseline ${ }^{\circledR}$ (3). Furthermore, 15 volunteers were instructed to apply soft paraffin containing $4 \%$ ethylhexyl dimethyl PABA for three weeks, followed by a challenge application after a two week rest phase, after which no skin sensitization was observed. Consistent with this result, 150 individuals subjected to a patch test with $7 \%$ ethylhexyl dimethyl PABA with $3 \%$ oxybenzone did not exhibit skin sensitization (4). Another study showed that application of soft paraffin containing 7\% ethylhexyl dimethyl PABA to 156 individuals did not cause sensitization (4). Finally, a slight stinging reaction was reported during the induction period when a mixture of $3 \%$ benzophenone and $8 \%$ ethylhexyl dimethyl PABA was applied to 90 individuals, but no skin sensitization was observed (4). 
Phototoxicity/Photosensitization. Ten guinea pigs had their ear hair removed and a mixture of 3\% oxybenzone and $7 \%$ ethylhexyl dimethyl PABA was applied to one ear several times, and 8-methoxypsoralen was applied to the ears of two guinea pigs as a positive control. The guinea pigs were then exposed to UV radiation for two hours. No phototoxicity was observed. Furthermore, no phototoxicity was observed when ethylhexyl dimethyl PABA was applied to the posterior of guinea pigs for $2 \mathrm{hr}$ followed by irradiation of $3 \mathrm{~J} / \mathrm{cm}^{2}$ at $320-400 \mathrm{~nm}$ (4).

No phototoxicity was observed in 26 individuals who were tested with $3 \%$ oxybenzone and $7 \%$ ethylhexyl dimethyl PABA (4). Furthermore, no phototoxicity was observed when 5\% ethylhexyl dimethyl PABA in ethanol was applied and the site was irradiated with $30 \mathrm{~J}$ (4).

Patch testing with a mixture of $2 \%$ oxybenzone and $7 \%$ ethylhexyl dimethyl PABA for $24 \mathrm{hr}$ was conducted on ten white-skin individuals. Following removal of the patch, the site was irradiated with UVA for $12 \mathrm{~min}$ followed by 1 MED (minimal erythema dose) of UVB. No phototoxicity was observed in this study (4). Furthermore, human subjects treated every $26 \mathrm{hr}$ with an emulsion of stearic acid $(3 \%)$, water $(91 \%)$, and $4 \%$ ethylhexyl dimethyl PABA showed no phototoxicity.

Ethylhexyl dimethyl PABA is harmless unless it is exposed to light. However, once activated by light, it directly damages DNA. Ethylhexyl dimethyl PABA in commercially available sunscreen products can be activated by UVA, and to a greater extent by UVB, when exposed to sunlight (10).

Toxicokinetics. To determine whether a new metereddose topical aerosol (MDTA) medication containing ethylhexyl dimethyl PABA as a skin penetration enhancer could enhance transdermal delivery of estradiol, estradiol MDTA containing ethylhexyl dimethyl PABA was applied to the abdomens of postmenopausal women for nine days and the levels of estradiol and estrone in the blood were measured daily via radioimmunoassay. Following MDTA treatment, $1 \mathrm{mg}$ of estradiol sprayed onto three adjacent areas of skin $\left(10 \mathrm{~cm}^{2}\right)$ on the abdomens of each subject did not induce skin irritation. Blood estradiol concentrations were measured in four women (aged between 54 and 63 years, body weight between 67 and $93 \mathrm{~kg}$ ). The average blood estradiol concentration was $53 \mathrm{pg} / \mathrm{mL}$ across the 9day study period, which was significantly greater than the reference value of $13 \mathrm{pg} / \mathrm{mL} .(p<0.001)$. This test confirmed that the MDTA containing ethylhexyl dimethyl PABA enhanced transdermal delivery of estradiol (9).

${ }^{14} \mathrm{C}$-labelled ethylhexyl dimethyl PABA in ethanol was applied to $100 \mathrm{~cm}^{2}$ of the forearms of each of four male and female subjects. The forearms were then covered with gauze for $24 \mathrm{hr}$ after the ethanol completely evaporated. Blood was collected after $0,2,4,8,24$, and $72 \mathrm{hr}$ and urine was collected for $24 \mathrm{hr}$. No radioactivity was found in the blood samples while $2.45 \%$ and $1.18 \%$ radioactivity were found in the urine samples of the male and female subjects, respectively (average \% of total radioactivity). The average radioactivity recovered after washing the skin at the application site was $95.7 \%$. Assuming that $0.5 \mathrm{mg} /$ $\mathrm{cm}^{2}$ was applied at a concentration of $8 \%$ to $1.8 \mathrm{~m}^{2}$, the total amount absorbed was $13 \mathrm{mg}$, or $0.2 \mathrm{mg} / \mathrm{kg}$ (4).

An oil-in-water emulsion lotion was used for an in vitro percutaneous penetration test, and guinea pig and human skin were used as the membranes. HEPES-buffered Hank's balanced salt solution containing gentamycin sulfate and bovine serum albumin was used as the aqueous solution in the receiving chamber. The total absorption rate of ethylhexyl dimethyl PABA transferred to the receiving chamber and the skin was $12.7 \pm 2.5 \%$. Evaluation of ethylhexyl dimethyl PABA metabolism was also included in this test. Guinea pig skin hydrolyzed approximately $13-35 \%$ of ethylhexyl dimethyl PABA transferred to the aqueous solution through esterase activity, while human skin hydrolyzed $37 \%$ of ethylhexyl dimethyl PABA (11).

The value used for skin absorption in humans for the risk assessment was $2.45 \%$ based on the limited skin absorption data.

Miscellaneous materials (including clinical data). Cell tests confirmed that ethylhexyl dimethyl PABA inhibited cell growth and DNA synthesis, and delayed cycle progression at $25-100 \mathrm{mg} / \mathrm{mL}$. The CI80-13S cell line, a model of mitochondrial dysfunction, showed greater cell growth inhibition in response to ethylhexyl p-methoxycinnamate (EHMC) and PABA than the other cell lines. The pretreatment of MM96L with ethidium bromide $(\mathrm{EtBr})$, which serve as mitochondrial inhibitors, followed by sunscreen treatment, resulted in apoptosis with increased uptake of ethidium bromide (12).

When keratinocytes exposed to 5 MED of sunlight were treated with sunscreen containing ethylhexyl dimethyl PABA (SPF 15), the number of DNA strand breaks observed here was at least 75 times higher than that in cells treated with sunscreen that did not contain ethylhexyl dimethyl PABA (13).

MCF-7, a human breast cancer cell line, was used to measure the estrogenic activity of ethylhexyl dimethyl PABA. Cell proliferation rates were evaluated by attaching the estrogen receptor of ethylhexyl dimethyl PABA, and $17 \beta$-estradiol was used as a positive control. The $\mathrm{EC}_{50}$ values for cell proliferation were $1.2 \mathrm{pM}$ and $2.63 \mathrm{pM}$ for $17 \beta$-estradiol and ethylhexyl dimethyl PABA, respectively (14).

\section{DOSE-RESPONSE ASSESSMENT}

After toxicological data were reviewed to determine the 
Table 3. Factors that determined the optimal point of departure

\begin{tabular}{|c|c|c|c|c|c|c|c|c|c|}
\hline Test type & $\begin{array}{c}\text { Test } \\
\text { animals/ } \\
\text { gender }\end{array}$ & $\begin{array}{l}\text { Number of } \\
\text { test animals }\end{array}$ & $\begin{array}{l}\text { Admini- } \\
\text { stration } \\
\text { route }\end{array}$ & $\begin{array}{l}\text { Duration } \\
\text { of } \\
\text { admini- } \\
\text { stration }\end{array}$ & Dose & $\begin{array}{l}\text { Test } \\
\text { items }\end{array}$ & Toxic results & $\begin{array}{c}\text { Classification } \\
\text { of material }\end{array}$ & Reference \\
\hline $\begin{array}{l}\text { Repeated } \\
\text { toxicity }\end{array}$ & $\begin{array}{l}\text { Rat/ } \\
\text { Male and } \\
\text { female }\end{array}$ & $\begin{array}{l}10 \text { males } \\
\text { and } 10 \\
\text { females, } \\
15 \text { animals/ } \\
\text { group }\end{array}$ & $\begin{array}{c}\text { Oral } \\
\text { (gavage) }\end{array}$ & $\begin{array}{c}4 \\
\text { weeks }\end{array}$ & $\begin{array}{l}0,100, \\
300, \text { or } \\
1,000 \mathrm{mg} / \\
\mathrm{kg} / \text { day }\end{array}$ & $\begin{array}{l}\text { Weight, } \\
\text { hematologic } \\
\text { examination, } \\
\text { histopathologic } \\
\text { examination }\end{array}$ & $\begin{array}{l}\text { Pigmentation in the tes- } \\
\text { tes, epididymis, and } \\
\text { spleen was observed at } \\
\text { high concentrations, } \\
\text { and liver toxicity was } \\
\text { observed. } \\
\text { These toxicities normal- } \\
\text { ized within four weeks } \\
\text { of convalescence, } \\
\text { except for oligozoosper- } \\
\text { mia in the epididymis. } \\
\text { Spleen pigmentation } \\
\text { was observed in } \\
\text { females at the dose of } \\
300 \text { mg/kg/d. This } \\
\text { observation was more } \\
\text { conspicuous at high } \\
\text { concentrations, and was } \\
\text { also observed in males. }\end{array}$ & $\begin{array}{l}\text { NOAEL } \\
100 \mathrm{mg} / \\
\mathrm{kg} / \text { day }\end{array}$ & 4,5 \\
\hline
\end{tabular}

Table 4. Systemic exposure dosage (SED) of ethylhexyl dimethyl PABA in cosmetics

\begin{tabular}{cccccc}
\hline \hline Adult & $\begin{array}{c}\text { Amount of cosmetics } \\
\text { daily used (g/day) }\end{array}$ & $\begin{array}{c}\text { Body weight } \\
(\mathrm{kg})\end{array}$ & $\begin{array}{c}\text { Dermal absorption } \\
\text { rate }(\%)^{*}\end{array}$ & $\begin{array}{c}\text { Maximum use of ethylhexyl } \\
\text { dimethyl PABA (\%) }\end{array}$ & $\begin{array}{c}\text { SED } \\
(\mathrm{mg} / \mathrm{kg} \mathrm{bw} / \mathrm{day})\end{array}$ \\
\cline { 2 - 6 } & 17 & 60 & 2.45 & 8 & 0.588 \\
\hline
\end{tabular}

${ }^{*}$ SCC (4).

** Domestic regulations on cosmetic products.

optimal toxicity reference value, the NOAEL of ethylhexyl dimethyl PABA was selected from a 4-week repeated dose toxicity study in rats. Ethylhexyl dimethyl PABA dissolved in corn oil was administered to rats at concentrations of 0 , 100,300 , and $1,000 \mathrm{mg} / \mathrm{kg} /$ day for four weeks by gavage, followed by four weeks of convalescence to assess the durability or reversibility of toxic effects. The results following the first four weeks showed toxicities such as increased weight and histological changes in the testes, epididymis, spleen, and liver. The assessment of reversible toxicity following four weeks of convalescence confirmed the absence of toxicity except for semen reduction in the epididymis, which was only observed in the treatment group given $1,000 \mathrm{mg} / \mathrm{kg} /$ day of ethylhexyl dimethyl PABA. Pigmentation of the spleen was observed among males subjected to high concentrations of ethylhexyl dimethyl PABA. This observation was more conspicuous among females treated with 300 and $1,000 \mathrm{mg} / \mathrm{kg} /$ day of ethylhexyl dimethyl PABA. Based on the pigmentation of the spleen, NOAEL was determined to be $100 \mathrm{mg} / \mathrm{kg} /$ day (5) (Table 3).

\section{EXPOSURE ASSESSMENT}

Systemic exposure dosage through the percutaneous pro- cess was calculated as follows:

SED $=$

$\frac{\mathrm{A}(\mathrm{g} / \text { day }) \times 1,000 \mathrm{mg} / \mathrm{g} \times \mathrm{C}(\%) / 100 \times \mathrm{DAp}(\%) / 100}{60 \mathrm{~kg}}$

SED (mg/kg/day): Systemic exposure dosage

A (g/day): Amount of cosmetics used daily

C (\%): Maximum allowable concentration of cosmetic ingredient

DAp (\%): Dermal absorption rate of cosmetic ingredient $60 \mathrm{~kg}$ : Average body weight

The body weight in exposure scenarios were based on the average adult weight of $60 \mathrm{~kg}$ (15). In accordance with the Guidelines on Safety Risk Assessment of Cosmetic Products, the daily dose of sunscreen product was limited to $17 \mathrm{~g}$ (Table 4).

\section{RISK CHARACTERIZATION}

The margin of safety (MOS) was calculated as follows: $\mathrm{MOS}=\mathrm{NOAEL} / \mathrm{SED}$

The NOAEL was based on animal testing data and eth- 
ylhexyl dimethyl PABA was not considered to be of concern if the MOS was 100 or above. Based on the MOS determined using the use limit of ethylhexyl dimethyl PABA among domestic cosmetic products, the health risk of ethylhexyl dimethyl PABA for use of sunscreen was 180.18 , which is significantly higher than 100 , which confirmed the safety of ethylhexyl dimethyl PABA.

\section{CONCLUSION}

Ethylhexyl dimethyl PABA is an organic derivative of water-soluble PABA (4-aminobenzoic acid) used as an ingredient in sunscreen and other cosmetics. Ethylhexyl dimethyl PABA induced pigmentation of the spleen in a four-week oral administration toxicity test in rats, and the NOAEL derived from this study was $100 \mathrm{mg} / \mathrm{kg} /$ day. No significant reproductive toxicity, genotoxicity, carcinogenicity, skin sensitization, skin irritation, or phototoxicity was observed in response to ethylhexyl dimethyl PABA administration. The optimal NOAEL for the risk assessment was determined to be $100 \mathrm{mg} / \mathrm{kg}$ /day based on a four-week repeated toxicity study in rats. The SED of ethylhexyl dimethyl PABA was 0.588 . The risk characterization demonstrated that ethylhexyl dimethyl PABA is safe to use in cosmetics in accordance with current MFDS regulations because the MOS exceeded 100 even at the maximum permitted concentration in cosmetics (8\%). However, the toxicological data used in the risk assessment are limited, and if new toxicological data are reported, further assessments should be performed as appropriate.

\section{ACKNOWLEDGMENTS}

This research was supported by a grant (14172MFDS975 and 19172MFDS221) from the Ministry of Food and Drug Safety.

\section{CONFLICT OF INTEREST}

The authors of this article hereby declare that there are no conflicts of interest.

Received February 21, 2019; Revised March 8, 2019; Accepted March 10, 2019

\section{REFERENCES}

1. DeSimone, E.M., 2nd. (1994) FDA proposes changes in sunscreen regulations. Am. Pharm., 34, 26-31.

2. HSDB (2011) Hazardous Substances Data Bank. Available from: https://toxnet.nlm.nih.gov/newtoxnet/hsdb.htm/.

3. TOXNET (2018) Toxicology Data Network. Available from: https://toxnet.nlm.nih.gov/cgi-bin/sis/search2/.

4. SCC (1999) Scientific Committee on Cosmetology, Reports of the Scientific Committeeon Cosmetology (9th series), Office for Official Publications of the European Communities, ISBN 92-828-8951-3, 1-1008.

5. NTP (2001) National Toxicology Program, Nominations in Review 2001.

6. Erol, M., Cok, L., BostanGayret, Ö., Günes, P., Yigit, O., Sayman, E., Gunes, A., Celik, D.S., Hamilcikan, S., Altinay, S. and Ercan, O. (2017) Evaluation of the endocrinedisrupting effects of homosalate (HMS) and 2-ethylhexyl 4dimethylaminobenzoate(OD-PABA) in rat pups during the prenatal, lactation, and early postnatal periods. Toxicol. Ind. Health, 33, 775-791.

7. Sigma-Aldrich (2018) MSDS Search and Product Safety Center. Available from: https://www.sigmaaldrich.com/korea/ safety-center-korea.html/.

8. Funk, J.O., Dromgoole, S.H. and Maibach, H.I. (1995) Sunscreen intolerance. Contactsensitization, photocontact sensitization, and irritancy of sunscreen agents. Dermatol. Clin., 13, 473-481.

9. Morgan, T.M., Reed, B.L. and Finnin, B.C. (1998) Enhanced skin permeation of sexhormones with novel topical spray vehicles. J. Pharm. Sci., 87,1213-1218.

10. Knowland, J., McKenzie, E.A., McHugh, P.J. and Cridland, N.A. (1993) Sunlight-induced mutagenicity of a common sunscreen ingredient. FEBS Lett., 324, 309-313.

11. Kenney, G.E., Sakr, A., Lichtin, J.L., Chou, H. and Bronaughh, R.L. (1995) In vitro skinabsorption and metabolism of Padimate-O and a nitrosamine formed in Padimate-Ocontaining cosmetic products. J. Soc. Cosmet. Chem., 46, 117127.

12. Xu, C. and Parsons, P.G. (1999) Cell cycle delay, mitochondrial stress and uptake ofhydrophobic cations induced by sunscreens in cultured human cells. Photochem. Photobiol., 69, 611-616.

13. Gulston, M. and Knowland, J. (1999) Illumination of human keratinocytes in thepresence of the sunscreen ingredient Padimate-O and through an SPF-15 sunscreenreduces direct photodamage to DNA but increases strand breaks. Mutat. Res., 444, 49-60.

14. Federal Register (1999) Federal Register. Rules and Regulations. Vol. 64, No. 98, 27671.

15. MFDS (2013) Ministry of Food and Drug Safety. MFDS Guidelines on Safety Risk Assessment of Cosmetic Products. 